Published in Scholarly Personae in the History of Orientalism, 1870-1930, ed. Christiaan

Engberts and Herman Paul (Leiden: Brill, 2019), pp. 1-16,

https://doi.org/10.1163/9789004406315_002

\title{
Introduction: Scholarly Personae in the History of Orientalism, 1870-1930
}

Herman Paul (Leiden University)

\section{Introduction}

In 1884, the Lebanese philologist Ibrahim al-Yaziji (1847-1906) filed a harsh complaint about Arabic studies in Europe when he reproached the then just-deceased Reinhart Pieter Anne Dozy (1820-1883) for never having visited the Middle East. How could Dozy or any of his colleagues in Europe claim Arabic expertise without ever having heard the language spoken on the street or sought the opportunity to meet and learn from native speakers? Al-Yaziji dissociated himself from generations of European Arabists when he concluded:

In spite of all research proficiency, in spite of the high ambitions, in spite of all patience in observing and writing, the man [Dozy] lacked the best means for understanding the Arabic language, the classical and the modern alike, because, to our knowledge, he has never traveled to one of the Arabic-speaking countries, such as Egypt or Syria, and conversed orally with only few Arabs, but learned the language solely from books, with the help of people among his fellow-countrymen whom are called Orientalists. ${ }^{1}$

By the late nineteenth century, such complaints were voiced not only in the Middle East, but also among younger European Orientalists such as Ignác Goldziher (1850-1921) and Martin Hartmann (1851-1918). ${ }^{2}$ Even at Dozy's alma mater, Leiden University, where Michael Jan de Goeje (1836-1909) faithfully built upon Dozy's legacy, disparaging words on Dozy's

\footnotetext{
${ }^{1}$ Cited after H. L. Fleischer, "Eine Stimme aus dem Morgenlande über Dozy's Supplément aux dictionnaires arabes," in Fleischer, Kleinere Schriften, 3 vols. (Leipzig: S. Hirzel, 1885-1888), 3: 615-641, at 619-620 (my translation).

2 Sabine Mangold, Eine "weltbürgerliche Wissenschaft": Die deutsche Orientalistik im 19. Jahrhundert (Stuttgart: Franz Steiner, 2004), 251-256.
} 
philological heritage could be heard. Christiaan Snouck Hurgronje (1857-1936) was the most outspoken of these critics. Although his doctoral dissertation on Het Mekkaansche feest (1880) still contained a few polite words on his Doktorgroßvater, his dissociation from Dozy became apparent when, in 1884, he deemed it necessary to travel to Mecca to do fieldwork in the center of Islam. ${ }^{3}$ Such fieldwork required different qualities than manuscript study as practiced by Dozy. It demanded not only active command of, in this case, Arabic, and the ability to gather relevant data, but also, as Snouck's adventures illustrated, social and political skills for acquiring funding, organizing research on foreign territory, and winning support from local communities - not to mention contempt for death in the case of scholars reckless enough to join the Hajj. ${ }^{4}$

Recent scholarship mostly treats this late nineteenth-century dissatisfaction with "armchair philology" as indicative of a paradigm shift that took place in Arabic studies. Suzanne Marchand, for example, distinguishes between the "lonely Orientalists" between 1820 and 1870, who devoted most of their energies to "specialized, historicist study," and a generation of "furious" Orientalists in the decades around 1900, who for various reasons dissociated themselves from a philological heritage and instead attached increasing value to conducting fieldwork, studying contemporary problems, and rendering services to colonial administrations. Consequently, in Marchand's assessment, "going there" became nothing less than a career requirement. ${ }^{5}$ Likewise, Sabine Mangold highlights the frustration that German Arabists around 1900 felt about the philological inheritance of especially Heinrich Leberecht Fleischer (1801-1888), the influential Leipzig Orientalist. Drawing on the cases of Carl Heinrich Becker (1876-1933) and Georg Kampffmeyer (1864-1936), among others, Mangold shows how an increasing interest in Arabic realia (economics, politics, religion) went hand-in-hand with growing disdain for philological text fetishism. ${ }^{6}$

Obviously, not all fields of Oriental studies underwent the same changes as did Arabic studies around 1900. At the time, Orientalism (Orientalistik, orientalisme) was the name of a cluster of fields, including but not limited to Islamic, Sanskrit, Indian, Chinese, and Japanese

\footnotetext{
${ }^{3}$ P. S. van Koningsveld, "Snouck Hurgronje zoals hij was: een bijdrage tot de waardering van de Nederlandse oriëntalistiek," De Gids 143 (1980), 763-784.

${ }^{4}$ For Snouck's adventures abroad, see also Arnoud Vrolijk and Richard van Leeuwen, Arabic Studies in the Netherlands: A Short History in Portraits, 1580-1950, trans. Alastair Hamilton (Leiden: Brill, 2014), 117-150.

${ }^{5}$ Suzanne L. Marchand, German Orientalism in the Age of Empire: Religion, Race, and Scholarship (Cambridge: Cambridge University Press, 2009), 102, 103, 220, 221.

${ }^{6}$ Mangold, Weltbürgerliche Wissenschaft, 256-266.
} 
studies. ${ }^{7}$ Although these subfields were related, and populated by overlapping groups of scholars, the historical trajectories of these emerging disciplines took different forms, depending, among other things, on national contexts, colonial politics, and commercial interests. Chinese studies, for example, underwent a transition almost opposed to that of Arabist studies. Here a philological ethos, defended in terms of Wissenschaftlichkeit, only emerged in the early twentieth century, after a period of mostly "practical," linguistically oriented teaching and writing aimed at educating interpreters and civil servants in particular. ${ }^{8}$ Field-specific patterns of development and national differences notwithstanding, the Arabist examples mentioned above hint at something important. They suggest that the emergence of new research questions, new methods, or new societal demands could change the very idea and reality of "being an Orientalist." Just as, at Leiden University, Jan Julius Lodewijk Duyvendak (1889-1954) represented a new type of Sinologist, compared to his predecessor Gustaaf Schlegel (1840-1903), so Goldziher, Hartmann, and Snouck represented a generation of Orientalists that conceived of themselves, their academic tasks, and their professional identities in terms that would have been implausible to Fleischer or Dozy.

This raises a question that so far has received only limited attention in the historiography of Orientalism, or in the history of the humanities more broadly: how did scholars experience and define their professional identities? ${ }^{9}$ What did it take for them to be a professor, Privatdozent, or non-academic researcher in the field of Oriental studies? What talents, virtues, or skills did this require? Also, how were these skills and virtues acquired or molded, especially but not only in educational practices, and what positive or negative models were invoked in contexts of socialization? If the models that Dozy and Fleischer had embodied came to be regarded as old-fashioned, what alternative models did Snouck, Hartmann, and Goldziher put in their place? And how were these different understandings of what it meant to be an Arabist, Egyptologist, or Sinologist related to professional identities in other areas of the Geisteswissenschaften, not to mention the emerging social sciences?

\footnotetext{
${ }^{7}$ The title of this volume follows nineteenth-century custom in using "Orientalism" as an umbrella term for the fields covered in the chapters that follow: Arabic, Semitic, Sanskrit, Chinese, and Japanese studies. With his 1978 book Orientalism, Edward W. Said would completely change the meaning of the term - but that chapter in the history of Orientalism falls outside the scope of this volume.

${ }^{8}$ Barend ter Haar, "Between the Dutch East Indies and Philology (1919-1974)," in Chinese Studies in the Netherlands: Past, Present and Future, ed. Wilt L. Idema (Leiden: Brill, 2014), 69-103.

${ }^{9}$ See, however, Henning Trüper, "Dispersed Personae: Subject-Matters of Scholarly Biography in NineteenthCentury Oriental Philology," Asiatische Studien 67 (2013), 1325-1360.
} 
Historians of science have developed the concept of "scientific" or "scholarly personae" to capture such different, overlapping, and often conflicting templates of scholarly selfhood that scholars developed, tried to appropriate, and sought to instill in their students. In what follows, I will (1) briefly introduce this concept in its three main variants, (2) explain why scholarly personae need to be studied empirically, in different fields of study, (3) make a case for Orientalism as a suitable case for trying out this concept, and (4) briefly summarize how the chapters brought together in this volume contribute to this project.

\section{Scholarly personae}

The newly founded journal Persona Studies represents a first approach to our subject: an approach that is largely rooted in cultural studies but appeals to scholars throughout the humanities. Central to this approach is the assumption that social life requires people to present themselves in ways that are recognizable to others as well as effective in granting people "identities" that help them navigate the demands of social life. Drawing on the old Latin persona, which among other things could refer to a mask worn by theater actors, advocates of this first approach conceive of personae as shorthand for identities that people articulate or "perform" in contextually sensitive ways. Although adherents of this first approach acknowledge that identities are not created ex nihilo, but are indebted to social traditions that make certain public identities appear as more plausible than others, the founding editors of Persona Studies, P. David Marshall and Kim Barbour, highlight the agency of individuals to shape their own personae. For Marshall and Barbour, then, personae are performances of identity, acts of self-fashioning, or tools for public "impression management" (to borrow a term from Erving Goffman). ${ }^{10}$ Accordingly, their analysis of the use and function of personae focuses near-exclusively on how individuals "produce," "perform," "enact," "inhabit," "negotiate," and "manage" their identities - in personalizing their game avatars or through playful mixture of professional role identities in work environments. ${ }^{11}$

Applied to the history of scholarship (or the history of science, as long as this is understood to cover the social sciences and humanities, too), this first approach encourages

\footnotetext{
${ }^{10}$ Erving Goffman, The Presentation of Self in Everyday Life (Garden City, NY: Doubleday, 1959).

${ }^{11}$ P. David Marshall and Kim Barbour, "Making Intellectual Room for Persona Studies: A New Consciousness and a Shifted Perspective," Persona Studies 1 (2015), 1-12.
} 
research on what Richard Karwan calls "scholarly self-fashioning."12 A noteworthy contribution to this research agenda comes from Mineke Bosch, who highlights the importance of scholarly self-fashioning in the claiming of academic authority. To be accepted as a trustworthy member of a scientific community, scholars not only need to have their research done, but also have to follow social conventions extending well beyond the realm of ideas. In Bosch's own words,

The scholarly identity makes use of specific bodily practices such as dietetics and routines of physical conduct (sexuality and sports for instance), but also of dress and other tools to keep up the appearance of a "truth-speaker" - beards and moustaches, or for women "ascetic dress" or "comfortable footwear" instead of high heels. ${ }^{13}$

Bosch thus uses the persona concept to draw attention to how scholars present themselves to each other, not only verbally, but also with their bodies and through their "emotion management." Like Marshall and Barbour, Bosch acknowledges the importance of culturally shared repertoires, but highlights the unique touches that individuals add in adapting such models to their own purposes. Consequently, she can attribute personae to individuals, speaking for instance about "[Robert] Fruin's scholarly persona” and "[Pieter] van Winter's scholarly persona." 14

This would be inconceivable within the second approach that must be mentioned here - an approach inspired by the anthropology of Marcel Mauss, but articulated most forcefully by Lorraine Daston and H. Otto Sibum in a seminal 2003 theme issue of Science in Context. For Daston and Sibum, scientific personae are cultural templates for the social role of a Gelehrter, savant, man of learning, or scientist. Although these templates can be adapted to new circumstances or even disappear in favor of others, as happened to the Naturforscher and the femme savant, they usually change at a slow or even very slow pace. As time-, place-, and discipline-transcending models of how to be a scientist, personae belong to what historians of

\footnotetext{
12 Scholarly Self-Fashioning and Community in the Early Modern University, ed. Richard Karwan (Farnham: Ashgate, 2013).

${ }^{13}$ Mineke Bosch, "Scholarly Personae and Twentieth-Century Historians: Explorations of a Concept," Low Countries Historical Review 131, no. 4 (2016), 33-54, at 43.

${ }^{14}$ Ibid., 45, 48. See also Mineke Bosch, "Persona and the Performance of Identity: Parallel Developments in the Biographical Historiography of Science and Gender, and the Related Uses of Self Narratives," L'Homme 24, no. 2 (2013), 11-22.
} 
science, with a nod to Fernand Braudel, call a histoire de longue durée. ${ }^{15}$ Consequently, personae are best regarded as collective entities, of which Daston and Sibum claim that they ontologically precede individual social existence:

To understand personae in this sense is to reject a social ontology that treats only flesh-and-blood individuals as real, and dismisses all collective entities as mere aggregates, parasitic upon individuals. Personae are as real or more real than biological individuals, in that they create the possibilities of being in the human world, schooling the mind, body, and soul in distinctive and indelible ways. ${ }^{16}$

Applying Daston's and Sibum's definition of scientific personae to the world of early modern learning, Gadi Algazi likewise treats personae as "materials that persons are made of." As his discussion of Johannes Kepler suggests, men of learning in early modern Europe could navigate between several personae. But as Kepler found out, they could not easily transform them: the power of these cultural institutions was too large for individuals to challenge. As collective representations, personae could not be changed "by force of personal decision." 17

This implies that real differences exist between the first and second approaches to the concept of scholarly personae. While the first one revolves around self-fashioning and selfpresentation, the second one focuses on broadly shared images of what it takes to be a scientist or man of learning. While the former zooms in on individuals in specific cultural settings, the latter engages in macro-level analysis, tracing scholarly personae across centuries. And if Daston and Sibum are right about the social ontologies underlying these persona concepts, these are more than differences in emphasis. Insofar as the two approaches are rooted in different anthropological assumptions, or different metaphysical views of human agency, they are irreconcilable.

\footnotetext{
${ }^{15}$ Frederick L. Holmes, "The Longue Durée in the History of Science," History and Philosophy of the Life Sciences 25 (2003), 463-470; Heiko Stoff, "Der aktuelle Gebrauch der 'longue durée' in der Wissenschaftsgeschichte," Berichte zur Wissenschaftsgeschichte 32 (2009), 144-158; Mathias Grote, What Could the "longue durée" Mean for the History of Modern Science? (Paris: Fondation Maison des sciences de l'homme, 2015).

${ }^{16}$ Lorraine Daston and H. Otto Sibum, "Introduction: Scientific Personae and Their Histories," Science in Context 16 (2003), 1-8, at 3-4.

${ }^{17}$ Gadi Algazi, “Exemplum and Wundertier: Three Concepts of the Scholarly Persona," Low Countries Historical Review 131, no. 4 (2016), 8-32, at 17, 23.
} 
Yet as Algazi rightly notes, we are not left with these alternatives. ${ }^{18}$ There is a third approach - a conception of scholarly personae of which Algazi is not entirely uncritical, but one that has the advantage of occupying a middle-range position between the biographical and the social, or between individuals engaged in "impression management," on the one hand, and powerful cultural institutions, on the other. This third approach, to which most chapters in this volume relate, is specifically tailored to situations of disagreement or uncertainty about the marks of a good scholar. Treating scholarly personae as "models" of what a scholar is, characterized by distinct combinations of talents, virtues, and/or skills, this third approach is premised on the assumption that personae never come in the singular. The persona that Dozy embodied became visible only when it was contrasted with others - when al-Yaziji and others began to criticize it, when Snouck began to adopt a different model of "how to be a scholar," or, much earlier, when Dozy and his colleagues advocated philological criticism as a mark of Wissenschaftlichkeit over against older, theologically-inspired modes of Arabic scholarship. ${ }^{19}$

Personae, in this third definition, are models, past or present, inherited or invented, of what it takes to be a scholar. Usually, they are attributed to influential individuals, who thereby come to serve as their embodiments, positively or negatively. Thus, for Carl Heinrich Becker, "Fleischer's era" referred to a time in the history of Orientalism when philological criticism such as practiced by Fleischer was regarded as the defining mark of an Orientalist scholar. ${ }^{20}$ This is not to say that Fleischer created his own persona, as the first approach would say, but rather that, for various reasons, the name Fleischer came to serve as shorthand for a persona that assigned great significance to source critical attitudes. The proper name was thus turned into a generic one, sometimes (not necessarily in Fleischer's case) even to the point of becoming a stereotype that no longer maintained a clear relation to its name-giver. ${ }^{21}$

The third approach encourages research on how personae served as models for imitation, emulation, and dissociation alike. It draws attention to how virtues, vices, skills, and talents were associated with specific individuals - the name of Heinrich Ewald (1803-1875)

\footnotetext{
18 Ibid., 10-11.

${ }^{19}$ On which see Mangold, Weltbürgerliche Wissenschaft, 29-77.

${ }^{20}$ Carl Heinrich Becker, Vom Werden und Wesen der islamischen Welt: Islamstudien, 2 vols. (Leipzig: Quelle \& Meyer, 1924-1932), 2: 484.

${ }^{21}$ Herman Paul, "The Virtues of a Good Historian in Early Imperial Germany: Georg Waitz's Contested Example," Modern Intellectual History 15 (2018), 681-709.
} 
being widely perceived as synonymous to dogmatism and arrogance, for instance ${ }^{22}-$ and how such embodied personae were remembered, positively or negatively, for the sake of advocating (or criticizing) certain constellations of virtues and skills. Also, it examines why scholarly personae were often defined in contrastive terms, as means for remedying the perceived shortcomings of other personae. Scholarly personae are thus a conceptual tool for distinguishing between competing models of how to be a scholar, as defined by historical agents or as distinguished in hindsight by historians of science. This implies that the third approach is particularly suited to examining clashes or tensions between generations, schools, traditions, or cultures, each with their own expectations regarding the virtues or skills characteristic of a scholar. ${ }^{23}$

\section{Case studies}

To what extent, then, did al-Yaziji's criticism of Dozy, with which I started, reflect a clash between different, perhaps even incompatible personae? Admittedly, the persona cultivated by al-Yaziji and his Arabic nationalist compatriots in the Syrian Scientific Society, among other associations, cannot be neatly classified as a scholarly persona (one that only professional scholars could appropriate). This, however, was the whole point of al-Yaziji's criticism: the philologist, poet, and journalist that was al-Yaziji had little patience for "bookish" scholars such as Dozy. His ideal of philological scholarship in the service of Arabic nationalism made him rebel against what he perceived as a much too narrow persona. ${ }^{24}$

At the same time, academic Orientalists defended "narrow" professional identities by dissociating themselves from "accidental Orientalists," or from non-academic authors writing about their experiences in the Near or Far East. ${ }^{25}$ Clearly, such criticism served purposes of academic boundary work. ${ }^{26}$ However, as Max Müller (1823-1900) experienced, such demarcation strategies could also be employed within the academic world, even against

\footnotetext{
${ }^{22}$ Christiaan Engberts, "Gossiping about the Buddha of Göttingen: Heinrich Ewald as an Unscholarly Persona," History of Humanities 1 (2016), 371-385.

${ }^{23}$ Herman Paul, "The Virtues and Vices of Albert Naudé: Toward a History of Scholarly Personae," History of Humanities 1 (2016), 327-338.

${ }^{24}$ Bassam Tibi, Arab Nationalism: Between Islam and the Nation-State, 3rd ed. (Basingstoke: Macmillan, 1997), 103-104.

${ }^{25}$ Barbara Spackman, Accidental Orientalists: Modern Italian Travelers in Ottoman Lands (Liverpool: Liverpool University Press, 2017).

${ }^{26}$ On which see T. F. Gieryn, "Boundary-Work and the Demarcation of Science from Non-Science: Strains and Interests in Professional Ideologies of Scientists," American Sociological Review 48 (1983), 781-795.
} 
famous Orientalists. When Müller, a prolific author of popular books on Hinduism and Sanskrit literature, was criticized for "cater[ing] to the public so long that scholarly work had become of only secondary consequence," 27 this showed that at least part of his work was seen as not befitting an Oxford professor. In Arie L. Molendijk's analysis, Müller's problem was that he tried to combine a scholarly persona with the persona of a sage in a time and place where this was deemed inappropriate. ${ }^{28}$ Likewise, Dozy's controversial study of the Israelites in Mecca, published in 1864, elicited critical feedback from colleagues who believed that speculation did not befit a serious student of Arabic - one that Dozy had been, judging by his Recherches sur I'histoire politique et littéraire de l'Espagne pendant le moyen âge (1848). The persona at stake in this controversy, then, was one that Dozy himself was perceived as having embodied in an earlier phase of his life. ${ }^{29}$

What these examples show is that scholarly personae can be located, or indeed were located, at different levels: within fields of research, in and outside of academic scholarship, as well as geographically, between Europe and the Arab world. If scholarly personae are often defined in contrastive terms, this implies that the contrasts can be drawn at different levels of generalization. This, in turn, suggests that a concept like scholarly personae is better not defined in the abstract. Empirical historical research is needed for adding muscle and flesh to the bones of the concept, that is, for showing when, how, and why historical agents felt a need to distinguish between different models of being a scholar.

\section{Orientalism}

Orientalism is obviously not the only field of study in which the scholarly persona concept (in the third variant) can be tested. In the past few years, attempts have been made to apply and refine the concept in fields as diverse as nineteenth-century history ${ }^{30}$ and twentieth-century

\footnotetext{
27 “Max Müller," The Nation 71 (1900), 343-344, at 343.

${ }^{28}$ Arie L. Molendijk, Friedrich Max Müller and the Sacred Books of the East (Oxford: Oxford University Press, 2016).

${ }^{29}$ Herman Paul, “Virtue Language in Nineteenth-Century Orientalism: A Case Study in Historical Epistemology," Modern Intellectual History 14 (2017), 689-715.

${ }^{30}$ Herman Paul, "The Heroic Study of Records: The Contested Persona of the Archival Historian," History of the Human Sciences, 26, no. 4 (2013), 67-83; Daniela Saxer, Die Schärfung des Quellenblicks: Forschungspraktiken in der Geschichtswissenschaft 1840-1914 (Munich: De Gruyter Oldenbourg, 2014), esp. 140-141, 172. See also How to Be a Historian: Scholarly Personae in Historical Studies, 1800-2000, ed. Herman Paul (Manchester: Manchester University Press, 2019).
} 
statistics. ${ }^{31}$ In the meantime, stimulating work has been done on how funding agencies in the early twentieth century helped shape scholarly personae. ${ }^{32}$ Still, the work has only just begun: comparisons with other disciplines, in and outside of the Geisteswissenschaften, are as of yet hardly possible. There are three reasons, then, why Orientalism in its late nineteenth and early twentieth-century European incarnations seems an interesting case for further exploring and testing the persona concept.

First, just like other emerging humanities disciplines at the time, late nineteenthcentury Orientalism, went through processes often referred to as "professionalization." Concretely, this meant that a field in which academic scholars had always found themselves accompanied by "a broad range of explorers, adventurers, and travelers: missionaries, theologians, and preachers; eccentrics, frauds, and crackpots; social reformers, political advocates, soldiers, spies, and diplomatic representatives of various European regimes" 33 tried to define itself in more academic terms. As Suzanne Marchand puts it: "Part of this effort was focused on pushing out, or at least getting around, the aristocrats, missionaries, and diplomats who still contributed much to Oriental studies": they were perceived as embodying different personae than those befitting a serious Orientalist. ${ }^{34}$

Secondly, Orientalism was a field fraught with religious, political, and ideological struggles, with perennial disagreement not only over the boundaries, but also over the very essence of what constituted Oriental studies. The degree of divergence was even such that, in Robert Irwin's assessment, "there was hardly an Orientalist type or a common Orientalist discourse" in Europe. ${ }^{35}$ Regardless of whether this is true or not, correspondences in which Oriental scholars continuously evaluated each other's scholarly conduct - not only their academic output, but also their teaching and their political engagement - suggest that issues of scholarly selfhood ranked high on the agenda, perhaps precisely because agreement was hard to reach. Time and again, Orientalists quarreled over the relation between academic

\footnotetext{
${ }^{31}$ In September 2018, the British Society for the History of Science hosted a session at its annual conference on "Scientific Personae and the (Dis-)Unity of Modern Statistics in Comparative Perspective, c. 1860-1960."

32 Pieter Huistra and Kaat Wils, "Fit to Travel: The Exchange Programme of the Belgian American Educational Foundation: An Institutional Perspective on Scientific Persona Formation (1920-1940)," Low Countries Historical Review, 131, no. 4 (2016), 112-134.

${ }^{33}$ Lawrence I. Conrad, "The Dervish's Disciple: On the Personality and Intellectual Milieu of the Young Ignaz Goldziher," Journal of the Royal Asiatic Society of Great Britain and Ireland 2 (1990), 225-266, at 265.

${ }^{34}$ Marchand, German Orientalism, 161.

${ }^{35}$ Robert Irwin, For Lust of Knowing: The Orientalists and Their Enemies (London: Penguin, 2007), 197.
} 
reputation and popularizing work, the desirability of studying living languages, or the pros and cons of doing advisory work for colonial administrations. ${ }^{36}$

A third and final reason as to why Oriental studies in the decades around 1900 is an interesting case study for testing the concept of scholarly personae is that intercultural exchanges such as al-Yaziji's criticism of Dozy were more likely to occur there than in history or statistics. In comparison to other humanities disciplines in Europe, Oriental studies was a field that found itself more frequently subjected to critical evaluation from outside of Europe. ${ }^{37}$ Did al-Yaziji's criticism of Dozy and his colleagues "whom are called Orientalists" have any impact on what it meant to be an Orientalist? How was the Orientalist persona affected by fieldwork in countries far away from European libraries and universities?

\section{This volume}

This volume thus approaches the world of Oriental studies between, roughly, 1870 and 1930, through the prism of scholarly persona. Its key question is a heuristic one: to what extent does the persona concept (in the third variant) contribute to a better understanding of unity and disunity among European Orientalists around 1900? In pursuing this question, the chapters that follow touch upon a range of sub-questions. What were the crucial factors that made some scholarly personae more successful, or at least more visible, than others? How did scholarly personae relate to non-scholarly ones, or to hybrid role identities like the "missionary-scholar," the "political professor," and the "public intellectual"? How did such personae affect day-to-day practices, such as the writing of book reviews - a genre in which evaluative standards often became quite explicit? And how different or similar were the subfields of Arabic, Semitic, Sanskrit, Chinese, and Japanese studies in these respects? Although this volume cannot possibly pretend to address these questions in satisfactory depth, it tries to put them on the agenda, so to speak, by showing in some detail what kind of historical analysis can be done through the prism of scholarly personae.

In his opening chapter, Holger Gzella shows how late nineteenth- and early twentiethcentury German Semitists (Hebraists and Aramaicists) struggled with the emerging persona of

\footnotetext{
${ }^{36}$ See, e.g., Martin Kramer, "Arabistik and Arabism: The Passions of Martin Hartmann," Middle Eastern Studies 25 (1989), 283-300.

${ }^{37}$ As documented in a fascinating recent collection of essays: The Muslim Reception of European Orientalism: Reversing the Gaze, ed. Susannah Heschel and Umar Ryad (London: Routledge, 2019).
} 
a "secular" university professor. Although this persona with its corresponding intellectual virtues was recognized as a new professional ideal across the discipline, it posed difficult dilemmas for scholars whose confessional loyalties made them prefer different configurations of the "sacred" and the "secular." Drawing on the cases of Gustav Bickell (1838-1906), Jacob Barth (1851-1914), Mark Lidzbarski (1868-1928), and Hans Bauer (1878-1937), Gzella shows how different German Semitists responded differently to these tensions, thereby suggesting that, for them, scholarly personae served as points of orientation more than as models for imitation.

As Arie L. Molendijk shows in his chapter on Max Müller, transgressing standards of conduct embodied by scholarly personae was not without consequences. Although Müller in many respects personified the philological virtues that late nineteenth-century students of Sanskrit perceived as marks of scholarly virtuosity, his popular lectures and publications targeted at "young ladies and easy-going people" (as one critic phrased it) were not seen as befitting a real academic. Likewise, the entrepreneurial qualities that Müller needed for successfully carrying out his Sacred Books of the East project (50 vols., 1879-1910) did not fit a philological persona. Like other nineteenth-century pioneers in "big humanities" projects, then, Müller had to navigate between multiple personae, thereby invariably invoking criticism from colleagues committed to distinguishing sharply between "scholarly" and "non-scholarly" personae.

Henning Trüper explores the moral dilemmas in which Orientalists could get entangled by presenting themselves and their colleagues as virtuous scholars, even in cases where this was less than obvious. When the Strasbourg Semitist Enno Littmann (1875-1958) edited the travel diary of the German Orientalist Julius Euting (1839-1913) from his journey to "Inner Arabia" in 1883-1884, Littmann tried to present Euting as an epitome of scholarly virtue, even if this required editing or reworking problematic passages in Euting's manuscript. Ironically, then, Littmann's defense of scholarly virtue required committing a philological vice - an observation that clearly challenges rigid distinctions between scholarly virtues and vices.

If Littmann was an arduous scholarly traveler - in the early 1900s, he conducted fieldwork in Eritrea and Ethiopia - so was the German-born Iranologist and Indologist Martin Haug (1827-1876). As Pascale Rabault-Feuerhahn shows in her chapter on Haug, German Indology underwent a transition similar to Arabic studies in that "armchair philology" was increasingly perceived as an old-fashioned mode of Orientalist scholarship. Yet, as illustrated 
by the opposition that Haug met with among his German colleagues after his Indian travels, this development was neither linear nor uncontested. The emergence of new scholarly personae might be better understood in terms of accumulation than in terms of succession. ${ }^{38}$

Timothy Barrett's chapter on Herbert Giles (1845-1935), the second Professor of Chinese at Cambridge University, nonetheless shows that certain scholarly practices, such as hostile book reviews in ad hominem language, became increasingly rare, and therefore more spectacular when they still made it into print. During Giles's lifetime, the lonely Sinologist, working in splendid isolation from others, was gradually replaced by a new persona: a university professor with colleagues and students, working in professional environments where "old-fashioned warriors" like Giles himself were no longer given much space. What this example shows, among other things, is that scholarly personae have to be understood against their social backgrounds. A discipline with journals and conferences requires more collegiality, and therefore different standards of public evaluation, than the non-institutionalized field that was Sinology in Giles's young years.

Just like Chinese studies, Japanese studies was a field to which Christian missionaries actively contributed. Also, in the closing decades of the nineteenth century, Buddhist priests from Japan played a major in furthering the study of Japanese religion. This leads Hans Martin Krämer to wonder to what extent the category of scholarly personae can be applied to the founding fathers of Japanese studies. Isn't the adjective too restrictive, especially if "scholarly" is treated as synonymous with "academic"? A persona perspective nonetheless enables Krämer to distinguish between three groups of actors in early Japanese studies: European philologists like August Pfizmaier (1808-1887) and Léon de Rosny (1837-1914), Japanese scholars and practitioners of Buddhism such as Akamatsu Renjō (1841-1919), Nanjō Bun'yū (1849-1927), and Kasawara Kenju (1852-1883), and, finally, European missionaries cum fieldworkers like Robbins Brown (1810-1880), James C. Hepburn (1815-1911), and Hans Haas (1868-1934).

Christiaan Engberts, finally, examines how classic tensions between nationalism and internationalism, such as experienced most dramatically in times of war, affected the scholarly persona as defined by Dutch and German Semitists in the 1910s. During World War I, Carl Heinrich Becker and Christiaan Snouck Hurgronje came to disagree sharply, not only over

\footnotetext{
${ }^{38}$ As suggested by Lorraine Daston and Peter Galison, Objectivity (New York, NY: Zone Books, 2007), 423 n. 18.
} 
Germany's colonial politics, but also, more importantly, on the relation between scholarly work and nationalist commitments. Was Snouck's scholarship still respectable when the Leiden Orientalist, much to Becker's annoyance, failed to acknowledge Germany's world historical role? Was international cooperation, for instance in the Encyclopaedia of Islam (1913-1938), still possible when its contributors found themselves taking different political stances?

Scholarly personae, then, were invoked at different occasions and contrasted in different ways. As shown by the chapters in this volume, personae were not etched in stone: they took shape in response to circumstances that varied across time and place. Often, they were articulated in response to perceived threats, or held up as alternatives to "others" in time (old-fashioned armchair philology), place (non-European learning), or social position (amateurism). This is hardly surprising: only when a mode of being a scholar was perceived as being under threat, or as new and not yet sufficiently accepted, did its defining features have to be articulated and defended. Interestingly, this not only explains why scholarly personae were debated most explicitly in contexts of controversy, but also why relative outsiders such as Ibrahim al-Yaziji often had a sharp eye for them.

This, finally, reveals one of the most important historiographical differences that the prism of scholarly personae can make. While existing literature on the history of Orientalism and the history of the humanities more broadly often focuses on diachronic development, especially in employing teleological categories like "professionalization" and "specialization," the prism of scholarly personae encourages historians to acknowledge synchronic variety, especially insofar as scholarly identities are concerned. Consequently, it is much better equipped to deal with non-European scholars like al-Yaziji, or with Buddhist students of Japanese religion as discussed in Krämer's chapter, than are histories that focus on the "development" of Western scholarship. Even if only applied to European case studies, the prism of scholarly personae naturally draws attention to "internal subaltern" groups, such as the Jewish and Catholic scholars examined by Gzella. If only for this reason, the promise of the perspective adopted in this volume reaches well beyond the field of Oriental studies. ${ }^{39}$

\footnotetext{
${ }^{39}$ A version of this introduction was presented at the École normale supérieure in Paris on 15 December 2017. Thanks to Pascale Rabault-Feuerhahn for hosting this event (together with Michel Espagne), to the participants for helpful feedback, and to the Netherlands Organization for Scientific Research (NWO) for generous funding.
} 


\section{Bibliography}

Algazi, Gadi. "Exemplum and Wundertier: Three Concepts of the Scholarly Persona." Low Countries Historical Review 131, no. 4 (2016): 8-32.

Becker, Carl Heinrich. Vom Werden und Wesen der islamischen Welt: Islamstudien. 2 vols. Leipzig: Quelle \& Meyer, 1924-1932.

Bosch, Mineke. "Persona and the Performance of Identity: Parallel Developments in the Biographical Historiography of Science and Gender, and the Related Uses of Self Narratives." L'Homme 24, no. 2 (2013): 11-22.

Bosch, Mineke. "Scholarly Personae and Twentieth-Century Historians: Explorations of a Concept." Low Countries Historical Review 131, no. 4 (2016): 33-54.

Conrad, Lawrence I. "The Dervish's Disciple: On the Personality and Intellectual Milieu of the Young Ignaz Goldziher." Journal of the Royal Asiatic Society of Great Britain and Ireland 2 (1990): 225-266.

Daston, Lorraine and H. Otto Sibum. "Introduction: Scientific Personae and Their Histories." Science in Context 16 (2003): 1-8.

Daston, Lorraine and Peter Galison. Objectivity. New York, NY: Zone Books, 2007.

Engberts, Christiaan. "Gossiping about the Buddha of Göttingen: Heinrich Ewald as an Unscholarly Persona." History of Humanities 1 (2016): 371-385.

Fleischer, H. L. “Eine Stimme aus dem Morgenlande über Dozy's Supplément aux dictionnaires arabes." In Fleischer, Kleinere Schriften, 3 vols. Leipzig: S. Hirzel, 18851888, 3: 615-641.

Gieryn, T. F. "Boundary-Work and the Demarcation of Science from Non-Science: Strains and Interests in Professional Ideologies of Scientists." American Sociological Review 48 (1983): 781-795.

Goffman, Erving. The Presentation of Self in Everyday Life. Garden City, NY: Doubleday, 1959.

Grote, Mathias. What Could the "longue durée" Mean for the History of Modern Science? Paris: Fondation Maison des sciences de l'homme, 2015.

Heschel, Susannah and Umar Ryad eds. The Muslim Reception of European Orientalism: Reversing the Gaze. London: Routledge, 2019.

Holmes, Frederick L. "The Longue Durée in the History of Science." History and Philosophy of the Life Sciences 25 (2003): 463-470. 
Huistra, Pieter and Kaat Wils. "Fit to Travel: The Exchange Programme of the Belgian American Educational Foundation: An Institutional Perspective on Scientific Persona Formation (1920-1940)." Low Countries Historical Review 131, no. 4 (2016): 112-134. Irwin, Robert. For Lust of Knowing: The Orientalists and Their Enemies. London: Penguin, 2007.

Karwan, Richard, ed. Scholarly Self-Fashioning and Community in the Early Modern University. Farnham: Ashgate, 2013.

Kramer, Martin. "Arabistik and Arabism: The Passions of Martin Hartmann." Middle Eastern Studies 25 (1989): 283-300.

Mangold, Sabine. Eine "weltbürgerliche Wissenschaft": Die deutsche Orientalistik im 19. Jahrhundert. Stuttgart: Franz Steiner, 2004.

Marchand, Suzanne L. German Orientalism in the Age of Empire: Religion, Race, and Scholarship. Cambridge: Cambridge University Press, 2009.

Marshall, P. David and Kim Barbour. "Making Intellectual Room for Persona Studies: A New Consciousness and a Shifted Perspective." Persona Studies 1 (2015): 1-12.

Molendijk, Arie L., Friedrich Max Müller and the Sacred Books of the East (Oxford: Oxford University Press, 2016).

N. N., “Max Müller,” The Nation 71 (1900), 343-344.

Paul, Herman. "The Heroic Study of Records: The Contested Persona of the Archival Historian." History of the Human Sciences 26, no. 4 (2013): 67-83.

Paul, Herman. "The Virtues and Vices of Albert Naudé: Toward a History of Scholarly Personae." History of Humanities 1 (2016): 327-338.

Paul, Herman. "Virtue Language in Nineteenth-Century Orientalism: A Case Study in Historical Epistemology." Modern Intellectual History 14 (2017): 689-715.

Paul, Herman. "The Virtues of a Good Historian in Early Imperial Germany: Georg Waitz's Contested Example." Modern Intellectual History 15 (2018): 681-709.

Paul, Herman, ed. How to Be a Historian: Scholarly Personae in Historical Studies, 18002000. Manchester: Manchester University Press, 2019.

Saxer, Daniela. Die Schärfung des Quellenblicks: Forschungspraktiken in der Geschichtswissenschaft 1840-1914. Munich: De Gruyter Oldenbourg, 2014. Spackman, Barbara. Accidental Orientalists: Modern Italian Travelers in Ottoman Lands. Liverpool: Liverpool University Press, 2017. 
Stoff, Heiko. "Der aktuelle Gebrauch der 'longue durée' in der Wissenschaftsgeschichte." Berichte zur Wissenschaftsgeschichte 32 (2009): 144-158.

ter Haar, Barend. "Between the Dutch East Indies and Philology (1919-1974)." In Chinese Studies in the Netherlands: Past, Present and Future, edited by Wilt L. Idema. Leiden: Brill, 2014): 69-103.

Tibi, Bassam. Arab Nationalism: Between Islam and the Nation-State. 3rd ed. Basingstoke: Macmillan, 1997.

Trüper, Henning. “Dispersed Personae: Subject-Matters of Scholarly Biography in Nineteenth-Century Oriental Philology." Asiatische Studien 67 (2013): 1325-1360.

van Koningsveld, P. S. "Snouck Hurgronje zoals hij was: een bijdrage tot de waardering van de Nederlandse oriëntalistiek." De Gids 143 (1980): 763-784.

Vrolijk, Arnoud and Richard van Leeuwen. Arabic Studies in the Netherlands: A Short History in Portraits, 1580-1950. Translated by Alastair Hamilton (Leiden: Brill, 2014). 
